\title{
EFFECT OF THE MATURATION PROCESS ON FERMENTED COCOA BEAN I: FREE AMINO ACIDS AND VOLATILE CARBONYLS
}

\author{
D. D. ABEYGUNASEKERA AND E. R. JANSZ \\ Ceylon Institute of Scientific and Industrial Research (CISIR), P.O. Box 787, \\ 363, Bauddbaloka Mawatba, Colombo 7, Sri Lanka.
}

(Date of receipt : 02 August 1988)

(Date of acceptance: 09. January. 1989)

\begin{abstract}
The maturation step in cocoa processing was originally introduced to reduce acidity of the cocoa bean. This study shows that maturation causes a decrease in free amino acids except glutamic and aspartic acid. Maturation also showed an increase in volatile carbonyls. The main increases were in diacetyl, formaldehyde, acetone, acetaldehyde, butyraldehyde (normal plus iso-) and valeraldehyde (normal plus iso-) levels. Although there appears to be a relationship between these two trends, the appearance of carbonyls appears to be caused not only by degradation of amino acids but also other processes for example the oxidative degradation of fatty acids. Roasting caused a further decline of amino acids and increase of carbonyls presumably due to the Strecker reaction.
\end{abstract}

\section{Introduction}

One of the problems of fermentation of cocoa beans is the prevalence of high acidity. This is the characteristic of cocoa beans produced in Malaysia, New Guinea and Uganda where the $\mathrm{pH}$ of the fermented bean has been reported to be between $4.6-4.8 .^{2,3,4}$ In order to circumvent this problem $\mathrm{Liau}^{2}$ proposed the process of "maturation" which simply meant holding the fermented cocoa beans in thin layers at ambient temperatures during which time little or no drying took place. During this time acetic acid is oxidised to $\mathrm{CO}_{2}$ by the Krebs cycle. This process was primarily proposed to overcome high acidity. and Schwartz et al. ${ }^{9}$ worked out several simple technologies to reduce acidity and thereby enhance the flavour of cocoa to be used in chocolate manufacture. In Sri Lanka acidity of cocoa bean had not been a major problem, mainly due to the fact that cocoa beans are largely under fermented. However, if cocoa is properly fermented (for four days or more) the acidity problem does arise in this country too.

In this study fermented cocoa beans that were treated by the maturation process were subjected to analysis for free amino acid and volatile carbonyl contents as it was felt that the process not only affected the acidity but might also affect the flavour and flavour precursors. This was indicated by a study of Packiyasothy ${ }^{6}$ which showed that volatile carbonyl content increased with the maturation process. 


\section{Experimental}

\subsection{Plant Material}

Cocoa bean was obtained from the Wariyapola Estate, Matale, Sri Lanka. The plant material was a mixture of the forestero and criolla varieties in the ratio of approximately $4: 1$. It was not practical to separate the varieties as both types of seeds sometimes exist within the same pod. Pods from different sections of the estate were pooled to obtain a random sample. Samples were drawn for experiments in both the major (September - December) and minor (April - June) seasons, which may be considered as indicative of two possible extreme conditions of climate for samples from this particular estate.

\subsection{Fermentation}

Cocoa beans were fermented according to the method of Ogutuga ${ }^{5}$ in six cane baskets. Each basket contained $12-17 \mathrm{~kg}$ of beans and pulp. The beans were fermented for four days with a 'turning' after $48 \mathrm{~h}$.

\subsection{Maturation}

Cocoa beans $(10-15 \mathrm{~kg})$ after fermentation for four days were subjected to 'maturation'. The beans were spread in the shade in the fermentory on coir matting in a layer of $5 \mathrm{~cm}$. The cocoa beans were held at an ambient temperature $\left(28^{\circ}-29^{\circ} \mathrm{C}\right)$ for $48 \mathrm{~h}$. Turning of beans were carried out after $24 \mathrm{~h}$. to ensure proper aeration. The cocoa beans were then washed and sun dried (3-4 days).

\subsection{Roasting}

Roasting was carried out for $30 \mathrm{~min}$. separately at $125^{\circ} \mathrm{C}$ or $165^{\circ} \mathrm{C}$ in a Memmert UL 50 oven.

\subsection{Determination of Amino Acids}

\subsubsection{Extraction of free amino acids}

Free amino acids were extracted by the method of Rohan and Stewart. ${ }^{7}$

\subsubsection{Quantification of amino acids}

Quantification was carried out using a Joel model $6 \mathrm{AH}$ amino acid analyser following the procedure described by Packiyasothy. ${ }^{6}$ 


\subsection{Determination of Carbonyls}

\subsubsection{Trapping of volatile carbonyls as 2,4-DNP derivatives}

Distilled water $(400 \mathrm{ml})$ was added to finely ground shell-free cocoa bean $(100 \mathrm{~g})$ and the mixture was distilled over $4 \mathrm{~h}$. The volatile compounds were trapped in isopentane : diethyl ether (1:1) using a modified Clavenger apparatus fitted with an iced water condenser $\left(5^{\circ} \mathrm{C}\right.$, Fryka-Therm water cooler). The extract was collected at half hourly intervals while adding fresh solvent (isopentane : diethyl ether, 1:1).

The carbonyls present in the total extract $(\sim 35 \mathrm{ml}$ ) were then converted to their 2,4-DNP derivatives. ${ }^{10}$ Although it is probable that recovery of carbonyls and derivatisation is not $100 \%$ as standard conditions were followed any errors introduced by these standard procedures would be common to different treatments. Fermented, matured, fermented and roasted, matured and roasted cocoa was subjected to such analysis.

\subsubsection{Preparation of standard 2,4-DNP derivatives}

2,4-DNP derivatives of 2,3 -butadione (diacetyl), formaldehyde, acetaldehyde, acetone, furfural, propanal, iso-butyraldehyde, n-butyraldehyde, iso-valeraldehyde, $n$-valeraldehyde and nonanaldehyde were prepared using the method described by Vogel. ${ }^{10}$.

\subsubsection{Separation of 2,4-DNP derivatives (Standards) TLC-UV densito- metry}

Standard solutions $(10.0 \mathrm{mg} / 10.0 \mathrm{ml})$ of $2,4-\mathrm{DNP}$ derivatives were prepared separately in chloroform. Aliquots $(5 \mu \mathrm{l})$ were spotted on neutral silica gel G-60 TLC plates $(500 \mu)$ : The plates were developed in the following solvent systems.

Solvent I - Hexane : Toluene $(40: 60)$

Solvent II $-\mathrm{CCl}_{4}:$ Hexane : Ethyl acetate $(70: 20: 10)$

(once in solvent I followed by twice in solvent II for ä good separation):

The plates were scanned at $436 \mathrm{~nm}$ using a Camag TLC-UV densitometer (Model 76502) equipped with a strip chart recorder (Camag Model 1107). The operating conditions were as follows ${ }^{6}-$

\begin{tabular}{|c|c|c|}
\hline Wave length & - & $436 \mathrm{~nm}$ \\
\hline Slit & - & $12 \mathrm{n}$ \\
\hline Band width & - & 10 \\
\hline Sensitivity & - & 6 \\
\hline Span & - & 8.8 \\
\hline
\end{tabular}




$\begin{array}{llr}\text { Recorder setting } & - & 100 \mathrm{mV} \\ \text { Recorder speed } & - & 5 \mathrm{~cm} / \mathrm{min} \\ \text { Scan speed } & - & 2 \mathrm{~mm} / \mathrm{sec}\end{array}$

\subsubsection{Standard curves}

Standard curves were plotted using standard solutions $(50 \mathrm{mg} / 100 \mathrm{ml}$ ) after suitable dilutions using chloroform as solvent. An aliquot of $10 \mu 1$ (1$5 \mu \mathrm{g})$ was spotted (keeping the spotting volume constant at $10 \mu \mathrm{l}$ ) on silica gel G-60 TLC plates $(300 \mu)$ developed as described in 2.6.3. The dried plates were scanned transversely for the standard curve. The technique of dual 12 $\mathrm{mm}$ non-overlapping bands was employed to ensure that the entire spot is covered when spot width reached $12 \mathrm{~mm}$ or a near value.

The standard curves were plotted accordingly (weight $\mu$ g versus peak area). The standard curves gave straight lines in the ranges of $(0.5 \mu \mathrm{g})$. As there was some doubt regarding reproducibility from plate to plate, the standard curves were used only to ensure that the peak area was proportional to the $2,4-\mathrm{DNP}$ derivative levels $(\mu \mathrm{g})$. Standard spots were run on each plate for quantification purposes.

\subsubsection{Separation of 2,4-DNP derivatives of carbonyls of cocoa}

The 2,4-DNP derivatives of carbonyls from cocoa distillates were prepared. These were dissolved in chlorofrom $(50 \mathrm{mg} / 25 \mathrm{ml})$ and aliquots $(5 \mu \mathrm{l})$ were spotted in TLC plates (silica gel G-60-500 ) and developed as described above. The plates were subjected to TLC-UV densitometric analysis as in 2.6.3.

\subsubsection{Quantification of 2,4-DNP derivatives of carbonyls}

The TLC plates (containing 2,4-DNP derivatives of cocoa carbonyls) were scannied in a Camag TLC-UV densitometer (Model 7.6502) equipped with a computing integrator (DP 88).

Each peak area was also calculated using a computer programme on a Commodore 64 Personal Computer. The peaks which were not picked up by the integrator were quantified by this method. The calibration of each run was carried out by spotting a known quantity of a sample on the same plate.

\subsection{Incubation Experiments with Amino Acids}

Samples of fermented cocoa beans (500 g) were macerated in a Waring blender. The macerated samples were treated as follows - 
One sample $(50 \mathrm{~g})$ was retained as a control. Another sample $(50 \mathrm{~g})$ was held at $50^{\circ} \mathrm{C}$ for $2 \mathrm{~h}$. A third sample $(50 \mathrm{~g})$ was made alkaline $(\mathrm{pH} 11.0)$ using $1 \mathrm{~N} \mathrm{Na} \mathrm{NaO}_{3}$ after which the $\mathrm{pH}$ was reduced to (4.2) using $2 \mathrm{~N} \mathrm{HCl}$. These treatments were introduced in an effort to deactivate enzymes and which was partially successful (Table 4 ).

The remaining samples $(50 \mathrm{~g}$ each) were incubated with the following amino acids $(50 \mathrm{mg} / 100 \mathrm{ml}$ distilled water) alanine, valine, leucine, threonine and glutamic acid. To all samples a solution $(5 \mathrm{ml})$ of sodium benzoate fixed concentration $(200 \mathrm{ppm})$ was added to prevent growth of microorganisms.

The samples were allowed to stand for $48 \mathrm{~h}$. (covered with polythene to prevent drying).

The volatiles were trapped and the carbonyls converted to their $2,4-$ DNP derivatives and quantified.

\section{Results}

\section{$3.1 \mathrm{pH}$}

The process of maturation resulted in the $\mathrm{pH}$ of the cocoa beans rising from 4.8 to 5.2 .

\subsection{Effect on Amino Acids}

Maturation caused a decline in amino acids. The only amino acids that showed increases were glutamic acid and aspartic acid. The roasting process also caused a decline in amino acid content. Details of results are shown in Table 1. 
Table 1. Effect of maturation and roasting of cocoa on individual amino acids

\begin{tabular}{|c|c|c|c|c|}
\hline Amino Acid & $\begin{array}{l}\text { Non-matured } \\
\text { (mg/100g) }\end{array}$ & $\begin{array}{l}\text { Mațured } \\
\text { (mg/100g) }\end{array}$ & $\begin{array}{l}\text { Non-matured } \\
\text { roasted } \\
(\mathrm{mg} / 100 \mathrm{~g})\end{array}$ & $\begin{array}{c}\text { Matured } \\
\text { roasted } \\
(\mathrm{mg} / 100 \mathrm{~g})\end{array}$ \\
\hline Lysine & 2.08 & 1.86 & 0.98 & 0.61 \\
\hline Histidine & 0.46 & 0.39 & 0.36 & 0.23 \\
\hline Arginine & 1.25 & 1.19 & 0.99 & 0.93 \\
\hline Aspartic acid & 2.19 & 3.48 & 1.45 & 1.58 \\
\hline Threonine & 4.54 & 3.24 & 2.00 & 1.52 \\
\hline Serine & 1.41 & 1.37 & 1.35 & 1.04 \\
\hline Glutamic acid & 3.93 & 4.99 & 1.01 & 1.33 \\
\hline Proline & 3.13 & 2.22 & 1.70 & 1.25 \\
\hline Glycine & 0.63 & 0.61 & 0.54 & 0.45 \\
\hline Alanine & 4.93 & 1.31 & 1.67 & 0.07 \\
\hline Valine & 5.39 & 2.59 & 2.14 & 1.61 \\
\hline Iso-leucine & 2.53 & 1.93 & 1.34 & 1.12 \\
\hline Leucine & 7.09 & 4.25 & 3.04 & 2.15 \\
\hline Tryosine & 2.10 & 1.76 & 1.43 & 1.06 \\
\hline Phenyl alanine & 3.49 & 3.35 & 2.24 & 1.44 \\
\hline TOTAL & 45.05 & 34.54 & 22.24 & 16.39 \\
\hline
\end{tabular}

Roasting was carried out at $165^{\circ} \mathrm{C}$

\subsection{Effect on Carbonyls}

Maturation had a dramatic effect on volatile carbonyls. The results are shown in Table 2. A TLC densitometric scan of the matured sample is shown in Figure 1 and the quantification of carbonyls is shown in Table 3. In the case of butyraldehyde and valeraldehyde, it was not possible to separate the normal and iso-forms. However, the bulk is likely to be the 
iso-form. ${ }^{1} \quad$ Roasting at $165^{\circ} \mathrm{C}$ resulted in an increased level of carbonyls as compared to $125^{\circ} \mathrm{C}$

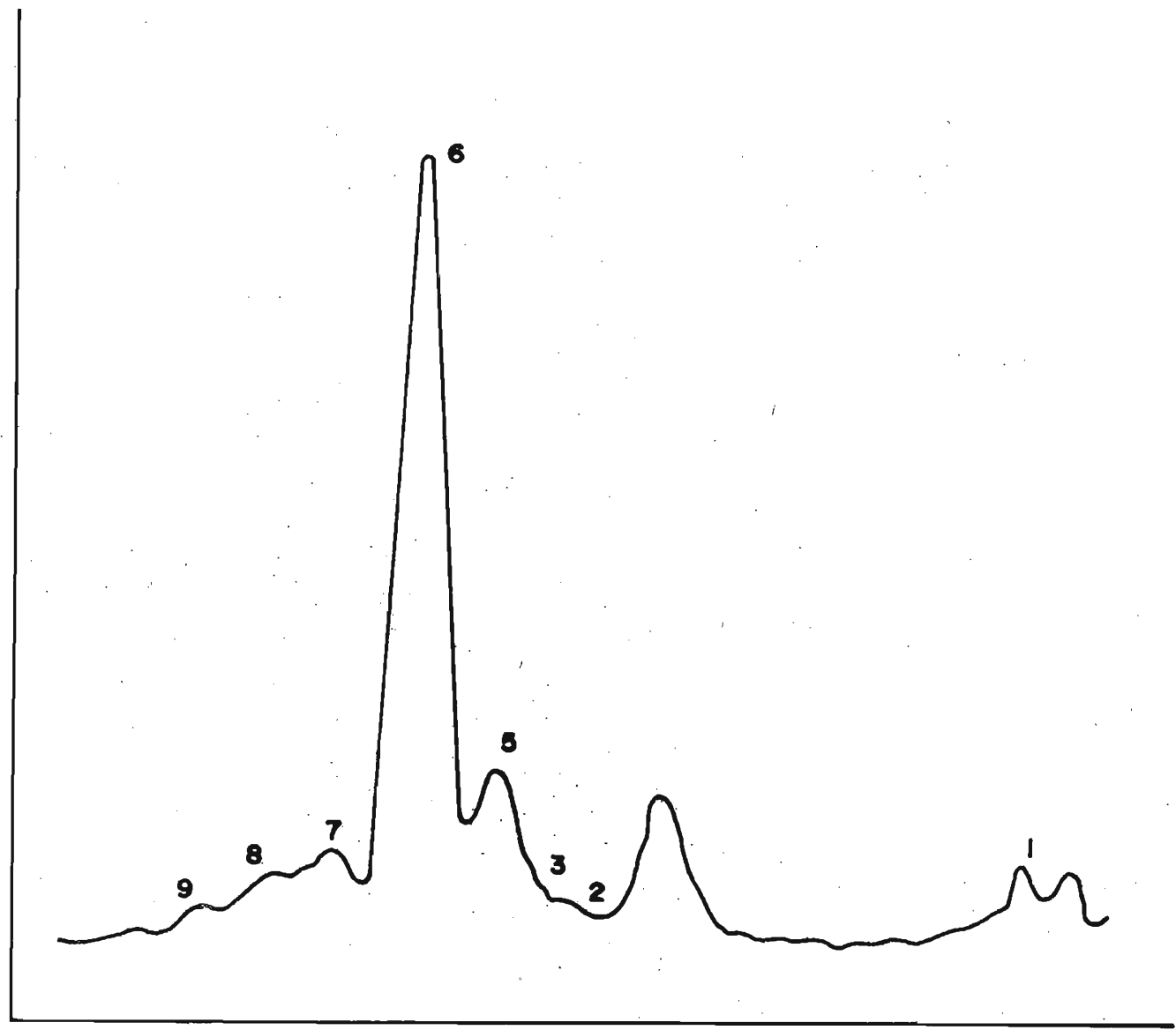

Figure 1. Densitometric pattern of separation of 2,4 DNP derivatives of cocoa
1. Diacetyl 2. Formaldehyde
3. Furfuraldehyde
4. Acetone 5. Acetaldehyde
6. Butyraldehyde ( $\mathrm{n}$ and Iso)

\section{Valeraldehyde ( $n$ and Iso) 8. Nonanaldehyde}

The peaks between 1 and 2 are unidentified.

A peak No. 4 (not in this particular scan) normally seen between 3 and 5 is normally propanaldehyde.

The large peak between 1 and 2 was unidentified and was possibly the mono-DNP derivative of diacetyl (Peak No. 1 was confirmed to be the di DNP derivative of diacetyl) 
Table 2. Mass of DNP derivatives of volatile carbonyls

$$
(\mathrm{g} / 100 \mathrm{~g})
$$

\begin{tabular}{lccc}
\hline Sample & Non Roasted & $\begin{array}{c}\text { Roasted } \\
\left(125^{\circ} \mathrm{C}\right)\end{array}$ & $\begin{array}{l}\text { Roasted } \\
\left(165^{0} \mathrm{C}\right)\end{array}$ \\
\hline Non-matured & 0.09 & 0.08 & 0.26 \\
Matured & 0.21 & 0.18 & 0.35 \\
\hline
\end{tabular}

Table 3. Effect of maturation and roasting on volatile carbonyls

\begin{tabular}{|c|c|c|c|c|}
\hline $\begin{array}{l}\text { Compound } \\
(2,4 \text { DNP } \\
\text { derivatives. }\end{array}$ & $\begin{array}{c}\text { Non-matured } \\
\text { cocoa } \\
(\mathrm{mg} / 100 \mathrm{~g})\end{array}$ & $\begin{array}{l}\text { Mature } \\
\text { cocoa } \\
(\mathrm{mg} / 100 \mathrm{~g})\end{array}$ & $\begin{array}{l}\text { Non-matured } \\
\text { roasted } \\
\text { cocoa } \\
(\mathrm{mg} / 100 \mathrm{~g})\end{array}$ & $\begin{array}{l}\text { Mature } \\
\text { roasted } \\
\text { cocoa } \\
(\mathrm{mg} / 100 \mathrm{~g})\end{array}$ \\
\hline Di-acetyl & 0.95 & 3.54 & 4.38 & 6.45 \\
\hline Formaldehyde & 0.73 & 3.68 & 2.02 & 5.88 \\
\hline Furfuraldehyde & 0.68 & 0.52 & 1.90 & 2.69 \\
\hline Acetone & 2.31 & 4.75 & 6.74 & 9.67 \\
\hline Acetaldehyde & 2.99 & 6.47 & 8.84 & 11.63 \\
\hline Iso-butyraldehyde 7 & 0.45 & 2.50 & 4.32 & 5.65 \\
\hline n-butyraldehyde & & & & \\
\hline Iso-valeraldehyde 7 & 0.47 & 2.40 & 3.61 & 4.03 \\
\hline $\mathrm{n}$-valeraldehyde & & & & $\therefore$ \\
\hline Nonanaldehyde & 0.03 & 0.04 & 0.05 & 0.03 \\
\hline
\end{tabular}

Roasting was carried out at $165^{\circ} \mathrm{C}$

\subsection{Incubation Experinients}

Incubation of cocoa with amino acids resulted in a marked increase of volatile carbonyls. The individual carbonyls formed are shown in Table 4. 


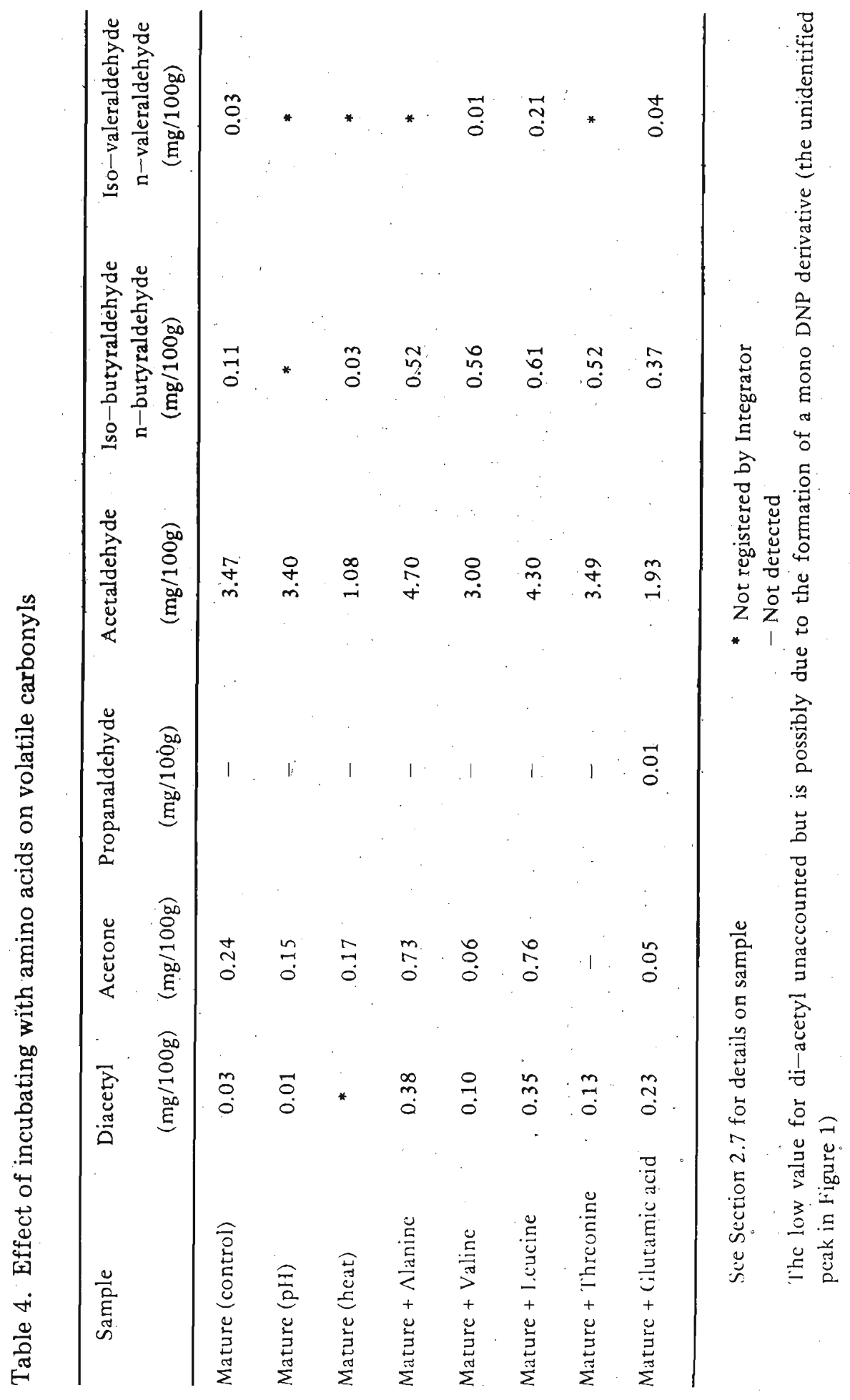




\section{Discussion}

The results showed that apart from a reduction in acidity the maturation process causes other chemical changes.

The process causes a loss of free amino acids which may be due to:-

(a) the migration of amino acids from bean to sweatings;

(b) a deamination process;

(c) a combination of the above two processes.

It is noted that although production of amino acids through hydrolysis of proteins may complicate interpretation of results, whatever the dominating mechanisms, overall free amino acid content declined on maturation.

Results also showed that there is a remarkable increase in the content of all volatile carbonyl compounds detected on maturation except for furfuraldehyde and nonanaldehyde. Many processes could account for increase in volatile carbonyls. Among them would be: (a) the deamination, decarboxylation and subsequent reaction of the carbon skeleton of amino acids and (b) degradative oxidation of fatty acids.

The incubation experiments clearly showed an interrelationship between amino acids and volatile carbonyls. The heat treated and $\mathrm{pH}$ adjusted controls indicated that the reactions are enzymatic. However, the carbonyls formed are not by a simple process of deamination and carboxylation. It appears that the process is more complex, involving possibly a general induction of free carbonyl formation. The presence of a straight chain $\mathrm{C}_{9}$ aldehyde and also large amounts of acetone and other reaction products of acetyl coenzyme $A$ indicates that fatty acid degradation also plays a part in carbonyl formation.

As expected the roasting increases carbonyl content and caused a decline of amino acids. This is a clear manifestation of the Strecker reaction which has been fully described previously. ${ }^{8}$ Here too the matured samples had a higher carbonyl content than the non-matured samples showing that the maturation process is not merely a process for reduction of acidity by the increase of aeration, but also affects the flavour forming reactions of cocoa bean.

\section{Acknowledgements}

The authors thank Dr. D. M. G. T. Chulatunge for writing the computer programme for interpretation of the TLC densitometric pattern, Mr. G. R. Liyanage for amino acids analysis and Mrs. I. Bandara for secretarial assistance. The study forms a part of the M. Phil. thesis (University of Colombo) of Mrs. D. D. Abeygunasekera. 


\section{References}

1. BAILEY, S. D., MITCHEL, D. G., BAZINET, M. L. \& WEURMAN, C. (1962) J. Food. Sci, 27 , 165

2. LIAU, T. L. (1976) Proc. East Malaysian Planters Assoc. Cocoa-Coconut Seminar.

3. LIAU, T. L. (1977) Proc. Symposium on improving quality of life in Malaysia : the role of chemistry. The Malaysian Institu te of Chemistry, Kuala Lumpor, 207.

4. NIIMOTO, H. (1975) Chemical Abstracts, 87P : 100879h (1977)

5. OGUTUGA, D. R. A. (1976) Cocoa Processing in Sri Lanka UNDP/FAO Project on Research and Experimentation on Minor Export Crops, Sri Lanka.

6. PACKIYASOTHY, E. V. (1982) Studies on the curing of cocoa and cocoa wastes M.Sc. Thesis, University of Sri Jayawardenepura, Sri Lanka.

7. ROHAN, T. A. \& STEWART, T. (1966) J. Food Sci, 31, 202

8. SCHONBERG, A. \& MOUBACHER, R. (1952) Chem. Rev, 50, 26

9. SCHWARTZ, P. B., WANG, D. Y. C. \& BRIDGER, R. (1981) Planters (Kuala Lumpur) 57, 584

10. VOGEL, A. I. (1968) A Textbook of Practical Organic Chemistry 3rd ed, Longmans Green and Co. Ltd. 